\title{
Reduced protection against hepatitis B virus following vaccination in patients with Type 1 (insulin-dependent) diabetes
}

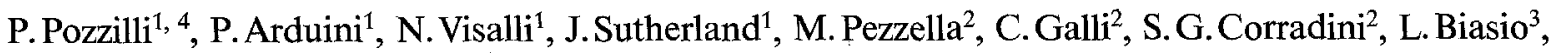 \\ E. A. M. Gale ${ }^{4}$ and D. Andreani ${ }^{1}$ \\ ${ }^{1}$ Endocrinologia (I) and ${ }^{2}$ Istituto Malattie Infettive, University of Rome "La Sapienza" and ${ }^{3}$ Institute Merieux, Rome, Italy; \\ ${ }^{4}$ Department of Diabetes and Immunogenetics, St Bartholomew's Hospital, London, UK
}

Summary. Twenty patients with well controlled Type 1 (insulin-dependent) diabetes of at least 10 years duration and 47 control subjects were vaccinated against the hepatitis B virus using the Hevac $B$ vaccine. The vaccine was administered into the deltoid region on three occasions at intervals of 1 month. Thereafter a fourth dose was given to subjects still negative for antibody to hepatitis $B$ surface antigen ( $\mathrm{Hbs} \mathrm{Ab})$. The median rise of $\mathrm{HbsAb}$ titres was $230 \mathrm{mIU} / \mathrm{ml}$ in normal subjects and $50 \mathrm{mIU} / \mathrm{ml}$ in diabetic patients $(p<0.001)$. Eight patients $(40 \%)$ failed to reach HbsAb titres above $30 \mathrm{mIU} / \mathrm{ml}$, the level considered to give optimal protection against the infection, whereas only one normal control subject failed to reach this level. Five patients (25\%) showed no response despite a fourth dose of the vaccine. There was an increased frequency of HLA-DR7 in low responders and a decreased $(<1.5)$ helper/suppressor lymphocyte ratio. Diabetic patients are thus less likely to mount a protective antibody response following vaccination against hepatitis. Since hepatitis B surface antigen is reported to be considerably more common in diabetic patients than control subjects, infection with hepatitis B virus may have a greater risk of chronicity in diabetes.

Key words: Immune response, B-hepatitis, Type 1 (insulin-dependent) diabetes, vaccination.
There is increasing evidence that multiple immunological abnormalities occur in patients with Type 1 (insulin-dependent) diabetes of long duration [1]. The number of circulating helper (CD4) cells is reduced [2], the helper/suppressor (CD4/CD8) lymphocyte ratio is decreased [3,4], phagocytic activity is impaired [5] and lymphocyte blastogenesis is reduced [6]. These are amongst the most consistent alterations reported in vitro and may well account for the greater susceptibility to infection in patients with poor metabolic control [7].

Antigenic challenges in vivo using the trivalent influenza vaccine have shown normal antibody titres [8] or slightly impaired response in patients with high levels of glycosylated haemoglobin [9]; furthermore, an intradermal test using various antigens to evaluate the delayed hypersensitivity response was normal in the majority of diabetic patients [10]. In vivo studies of the immune response may therefore give a better indication as to whether secondary immunodeficiency is a feature of patients with diabetes of long duration. The response to a viral infection may be reduced and it is worth noting that hepatitis B surface antigen ( $\mathrm{HbsAg}$ ) has been detected to be 11-fold more frequent in diabetic patients than normal subjects [11] and a greater frequency of B hepatitis has also been reported [12]. It is estimated that $10 \%$ of subjects positive for $\mathrm{HbsAg}$ may evolve to chronic hepatitis [13].

In light of these observations diabetic patients may be considered at increased risk if they come in contact with the hepatitis $B$ virus and vaccination should be considered. We report the data obtained following the administration of the hepatitis $B$ vaccine in patients with Type 1 diabetes of long duration.

\section{Subjects and methods}

Twenty patients with Type 1 diabetes (12 males and 8 females, mean age $34 \pm 13$ ) with a mean duration of diabetes of $13 \pm 3$ years were investigated. Forty-seven normal hospital personnel $(28$ males and 19 females, mean age $32 \pm 10$ ) were included as age- and sexmatched control subjects.

Criteria for vaccination were as follows: (a) insulin dependency of at least 10 years; (b) negativity for $\mathrm{Hbs} \mathrm{Ag}, \mathrm{HbsAb}$ and $\mathrm{HbcAb}$; (c) absence of proliferative retinopathy and other severe diabetic complications; (d) absence of any active infection at the time of entry; (e) $\mathrm{HbA}_{1}$ less than $9 \%$ (normal range 4-7\%). Subjects were vaccinated with the Hevac B vaccine (Pasteur Vaccins, Paris, France), which is prepared from plasmas of healthy asymptomatic carriers negative for $\mathrm{HBe}$ antigen and for anti-HIV antibodies. Its manufac- 
turing process ensures a highly purified and inactivated $\mathrm{HBsAg}$ preparation. The vaccine ( $5 \mu \mathrm{g}$ in $1 \mathrm{ml}$ solution) was injected subcutaneously into the deltoid region on three occasions at intervals of 1 month. If subjects were still negative for anti-HbsAg (HbsAb) after the third injection, a fourth injection was given 3 months later.

In diabetic patients before and after the third dose of vaccine, an in vivo evaluation of cell mediated immunity was performed by using the Multitest, a device by which simultaneously different antigens (streptococcus, tetanus, diphtheria, proteus, candida, tricophiton and glycerine as control) are administered subcutaneously in the forearm; the immune reaction is measured at $48 \mathrm{~h}$ and a mean score calculated [10].

Venous blood samples were collected before and after the third dose of vaccine for measurement of HbsAb titres using a commercially available radioimmunoassay kit (Abbott). The following measurements were also made in diabetic patients: (a) blood glucose, urea, creatinine, total protein, transaminase, bilirubin and $\mathrm{HbA}_{1}$. (b) lymphocyte phenotypes using monoclonal antibodies defining total T (CD3), helper (CD4), suppressor/cytotoxic (CD8) lymphocytes and activated cells with receptors for interleukin-2 (anti-TAC). (c) HLA phenotyping, including the DR-DQ specificities.

\section{Results}

No side effects were recorded in either group following the three doses of the Hevac B vaccine; biochemical parameters did not change thereafter in the control group (data not shown). Normal subjects showed a median titre of $\mathrm{HbsAb}$ of $230 \mathrm{mIU} / \mathrm{ml}$ after the third injection; only 3 of them $(6 \%)$ did not respond after the third dose and required a fourth injection which

Table 1. Laboratory data of patients with Type 1 (insulin-dependent) diabetes following vaccination with Hevac $B$ vaccine against the hepatitis $B$ virus (values are mean $\pm S D$ )

\begin{tabular}{lcc}
\hline & $\begin{array}{l}\text { Before } \\
\text { vaccination }\end{array}$ & $\begin{array}{l}\text { After the 3rd } \\
\text { dose }\end{array}$ \\
\hline \%CD4+ve cells & $40 \pm 4$ & $37 \pm 6$ \\
\%CD8 + ve cells & $25 \pm 4$ & $25 \pm 4$ \\
CD4/CD8 ratio & $1.6 \pm 0.4$ & $1.5 \pm 0.4$ \\
$\% \mathrm{TAC}+$ ve cells & $1.5 \pm 3$ & $3.1 \pm 2$ \\
Multitest (score) $^{\mathrm{a}}$ & $8.3 \pm 8$ & $4.1 \pm 3.5$ \\
$\% \mathrm{HbA}_{3}$ & $7.2 \pm 1.4$ & $6.9 \pm 1.3$ \\
HbsAb titre (mIU/ml) (median) & - & 50.4 \\
\hline
\end{tabular}

Median HbsAb in control subjects: $230 \mathrm{mIU} / \mathrm{ml}(p<0.001$ Mann Whitney $U$ test). a Normal value in control population: $\mathrm{CD} 4=40-50 \% ; \quad \mathrm{CD} 8=20-30 \% ; \quad \mathrm{CD} 4 / \mathrm{CD} 8 \quad$ ratio $=2-2.5$; $\mathrm{TAC}=1-4 ;$ Multitest $=7-10$ then induced a normal HbsAb titre. According to WHO criteria, HbsAb titres between 10 and $30 \mathrm{mIU} /$ $\mathrm{ml}$, even if low, may still induce protection from $\mathrm{B}$ hepatitis infection; in our control group optimal protection (>30 mIU/ml) was obtained in $98 \%$ of subjects.

Data of the diabetic patients are shown in Table 1. A low median $\mathrm{HbsAb}$ titre $(50 \mathrm{mIU} / \mathrm{ml})$ and a reduced CD4/CD8 lymphocyte ratio (the latter is a frequent feature in diabetic patients with disease of long duration) were the most striking features despite an apparently normal generation of TAC positive cells. Patients were well controlled throughout the period of investigation (mean $\mathrm{HbAl}$ was $7 \%$ ) and the Multitest was normal (a reduced score following a specific challenge is expected even in normal subjects). In total only 12 patients $(60 \%)$ developed $\mathrm{HbsAb}$ titres above $30 \mathrm{mIU} / \mathrm{ml}$; out of 8 patients (40\%) with titres below $30 \mathrm{mIU} / \mathrm{ml}, 5$ $(25 \%)$ did not show any response after the third injection of vaccine and therefore received a fourth dose; even so, the HbsAb titre was still undetectable. The characteristics of these 5 subjects are shown in Table 2 . These patients did not differ much in terms of their immune response from those who responded to the virus, except that activated $T$ cells appeared not to be generated following vaccination; three of the 5 non-responsive patients were HLA DR7 positive versus 2 in the other 15 patients, and this phenotype is known to be associated with low HbsAb titre following $\mathrm{B}$ hepatitis vaccination [14].

\section{Discussion}

We found that at least $40 \%$ of patients with well controlled Type 1 diabetes of long duration had a reduced immune response to hepatitis $B$ virus following vaccination, implying inadequate protection against infection with the virus. The type and route of administration of the vaccine gave optimal HbsAb titres in the control group, suggesting that the deltoid region (and not the gluteal region in which a high prevalence of low responses has been observed [15]) should be the site of preference for the administration of $B$ hepatitis vaccine.

Table 2. Individual data (pre- and post-vaccination) of 5 patients with no generation of $\mathrm{Hbs} A b$ titres despite a fourth dose of Hevac B vaccine. (NA = data not available)

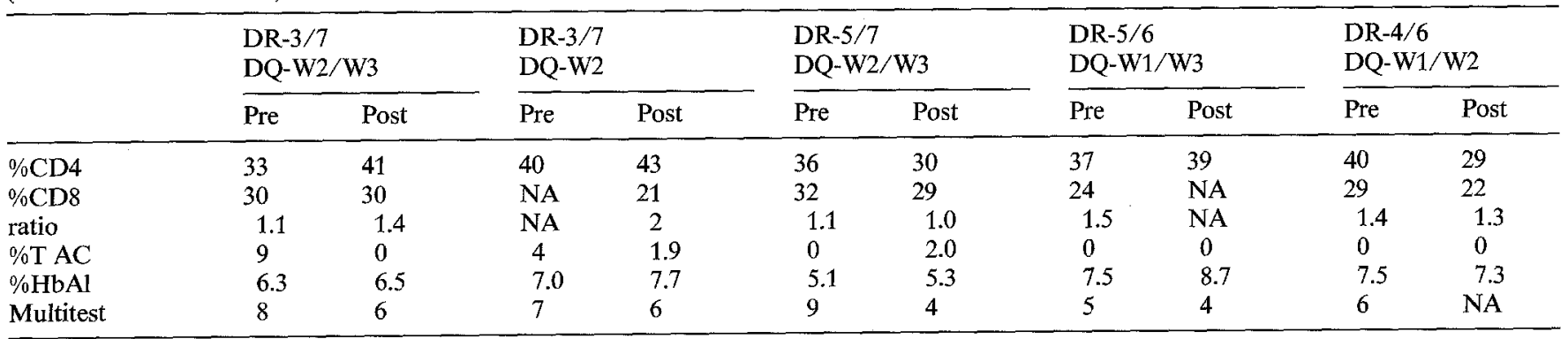


Genetic factors may be involved but it is likely that immunological disturbance is mainly responsible for the impaired $\mathrm{HbsAb}$ titre observed in patients with Type 1 diabetes. An increased prevalence of HLA-DR7 in low responders and of HLA-DR3 in high responders to the B hepatitis virus has been reported in normal individuals [14]; it seems surprising that patients with Type 1 diabetes did not show higher HbsAb titres (the highest $\mathrm{HbsAb}$ titre observed was $170 \mathrm{mIU} / \mathrm{ml} \mathrm{com-}$ pared to $850 \mathrm{mIU} / \mathrm{ml}$ in the control group) since this disease is associated with HLA-DR3. However we found HLA-DR7 to be present in 3 of 5 patients who had no response at all to the vaccine despite a fourth dose and this may explain the lack of HbsAb generation.

The immunological status of the patients, in particular an impaired CD4/CD8 lymphocyte ratio, may have contributed to the low HbsAb titres observed. The lymphocyte ratio, despite its poor specificity, is a simple and widely used test for evaluation of the cell mediated immune response [16] and is reported to be reduced in patients with a long duration of disease [3, 4]. Immunoregulatory lymphocyte subsets have a major role in the induction of a primary immune response (as in the case of the $B$ hepatitis vaccine) and any abnormality of these cells in number and/or function may result in impaired generation of a specific cell mediated and humoral immune response. In the case of a secondary immune response (as might be the case with vaccination with influenza virus or a multiple antigenic challenge like the Multitest) a memory $T$ cell is responsible for the expansion of a clone of sensitised lymphocytes and this process does not require, as does the primary response, a normal $\mathrm{CD} 4 / \mathrm{CD} 8$ lymphocyte ratio [17]. This may explain our finding that in diabetic patients a normal antibody titre is generated following the influenza vaccine [9] but not the $B$ hepatitis vaccine. Poor metabolic control may cause impaired immune responses in diabetic patients [18]; but this was not the case in our study since all patients were well controlled throughout the period of follow-up, suggesting that the primary defect is immunological.

In conclusion, previous observations that patients with Type 1 diabetes are more likely to be carriers of HbsAg [11] and have increased frequency of B hepatitis [12] and that low HbsAb titres are observed following vaccination with the hepatitis $B$ virus, suggest that there may be a greater risk of chronic infection in these patients. Although there is currently no data to suggest this, adequate protection might be achieved by administering repeated doses of vaccine at 1 year after the first dose in addition to immunostimulatory drugs; studies in this direction are in progress in our hospital.

Acknowledgements. This work was supported by Grants from the Ministero P.I. Italy no. 2.12.1.44, the Anglo Italian Fund for Research into Diabetic Vascular Disease and the Istituto Merieux Italia. We wish to thank Prof. C. Mazzilli and her team for providing the HLA typing.

\section{References}

1. Drell DW, Notkins AL (1987) Multiple immunological abnormalities in patients with Type 1 (insulin-dependent) diabetes mellitus. Diabetologia 30: 132-143

2. Pozzilli P, Zuccarini O, Tavicoli M, Andreani D, Sensi M, Spencer KM, Bottazzo GF, Beverley PCL, Kyner JL, Cudworth AG (1983) Monoclonal antibodies define abnormalities of T lymphocyte subsets in diabetes. Diabetes 32:91-94

3. Herold KC, Huen H, Gould L, Traisman H, Rubenstein AH (1984) Alterations in lymphocyte subpopulations in Type 1 (insulin-dependent) diabetes mellitus: exploration of possible mechanisms and relationships to autoimmune phenomena. Diabetologia 27: 102-105

4. Pozzilli P, Negri M, Visalli N, Pagani S, Beales $P$, Andreani D (1986) Impaired CD4/CD8 lymphocyte ratio in patients with long-standing diabetes mellitus. IRCS Med Sci 14: 648-649

5. Bagdade JD, Nielson KL, Bulger RJ (1972) Reversible abnormalities in phagocytic function in poorly controlled diabetic patients. Am J Med Sci 263: 451-456

6. McCuish AC, Jordan J, Campbell CJ, Duncan LJP, Irvine WJ (1974) Phytohaemagglutinin lymphocyte transformation and circulating lymphocyte subpopulations in insulin-dependent diabetes. Diabetes 23: 708-712

7. Robertson HD, Polk HC (1974) The mechanisms of infections in patients with diabetes mellitus: a review of leucocyte malfunction. Surgery $785: 123-128$

8. Pozzilli P, Gale EAM, Visalli N, Baroni M, Crovari P, Frighi V, Cavallo MG, Andreni D (1986) The immune response to influenza vaccination in diabetic patients. Diabetologia 29: $850-854$

9. Diepersloot RJA, Bouter KP, Beyer WE, Hoekstra JBL, Masurel $N$ (1987) Humoral immune response and delayed type hypersensitivity to influenza vaccine in patients with diabetes mellitus. Diabetologia 30: 397-401

10. Pozzilli P, Pagani SD, Arduini P, Visalli N, Cioccia GP, Negri M, Andreani D (1987) In-vivo determination of cell mediated immunity in diabetic patients using a new intradermal antigen dispenser. Diabetes Res 6 (in press)

11. Madalinski K, Brzosko W, Malezewski M, Czyzyk A (1971) Australia Antigen in sera of diabetic patients. Lancet I: 701-702

12. Muller R (1969) Frequency of liver disease in diabetes mellitus. Acta Diabetol Lat 6: 614-622

13. Alter HJ (1982) The evolution, implications and applications of the Hepatitis B vaccine. JAMA 247: 2272

14. Walker M, Szmuness W, Stevens C, Rubinstein P (1981) Genetics of anti-HBs responsiveness HLA-DR7 and non-responsiveness to Hepatitis vaccination. Proceedings American Association of Blood Banks, 34th Annual Meeting (Abstracts 21) 5:601

15. Pead PJ (1986) Immune responses to Hepatitis B vaccination in hospital staff. Biomed Pharmacother 40: 251-253

16. Reinherz EL, Rubinstein A, Geha RS, Strelkauskas AJ, Rosen FS, Schlossman SF (1979) Abnormalities of immunoregulatory T-cells in disorders of the immune function. N Engl J Med 301: 1018-1022

17. Beverley PCL, O'Flynn P, Wallace D, Lamb JR, Boylston AW, Linch DC (1986) Regulation of activation and proliferation in Tcells. In: Reinherz FL, Haynes BF, Nadler LM, Bernstein ID (eds) Leucocyte Typing II, Regulation of activation and proliferation in T-cells. Vol 1. Springer, Berlin Heidelberg New York Tokyo, pp 427-439

18. Rayfield EJ, Ault MJ, Keush GT, Brothers MJ, Nechemias C, Smith H (1982) Infections and diabetes: the case for glucose control. Am J Med 72: 439-450

Received: 10 August 1987

Dr. P. Pozzilli

Department of Diabetes and Immunogenetics

St. Bartholomew's Hospital

West Smithfield

London EC1A 7BE

UK 